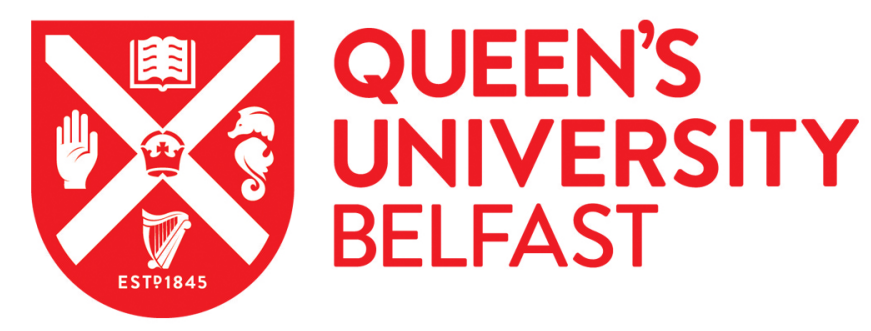

\title{
Smoked cigarette butt leachate impacts survival and behaviour of freshwater invertebrates
}

Green, D. S., Kregting, L., \& Boots, B. (2020). Smoked cigarette butt leachate impacts survival and behaviour of freshwater invertebrates. Environmental Pollution, 266, [115286]. https://doi.org/10.1016/j.envpol.2020.115286

\author{
Published in: \\ Environmental Pollution
}

\section{Document Version:}

Peer reviewed version

\section{Queen's University Belfast - Research Portal:}

Link to publication record in Queen's University Belfast Research Portal

\section{Publisher rights}

(C) 2020 Elsevier Ltd.

This manuscript is distributed under a Creative Commons Attribution-NonCommercial-NoDerivs License

(https://creativecommons.org/licenses/by-nc-nd/4.0/), which permits distribution and reproduction for non-commercial purposes, provided the author and source are cited.

\section{General rights}

Copyright for the publications made accessible via the Queen's University Belfast Research Portal is retained by the author(s) and / or other copyright owners and it is a condition of accessing these publications that users recognise and abide by the legal requirements associated with these rights.

Take down policy

The Research Portal is Queen's institutional repository that provides access to Queen's research output. Every effort has been made to ensure that content in the Research Portal does not infringe any person's rights, or applicable UK laws. If you discover content in the Research Portal that you believe breaches copyright or violates any law, please contact openaccess@qub.ac.uk. 
1 Please see link for Publisher's version: https://doi.org/10.1016/j.envpol.2020.115286

2 Smoked cigarette butt leachate impacts survival and behaviour of freshwater 3 invertebrates

4 Dannielle Senga Green ${ }^{1 *}$, Louise Kregting ${ }^{2}$, Bas Boots ${ }^{1}$

$5{ }^{1}$ Applied Ecology Research Group, School of Life Sciences, Anglia Ruskin University, 6 Cambridge, CB1 1PT, United Kingdom.

$7 \quad{ }^{2}$ Marine Biology Station, Queen's University Belfast, Portaferry, Newtownards, BT22 IPF,

$8 \quad$ United Kingdom.

$9 \quad$ *Corresponding author: dannielle.green@aru.ac.uk.

10 Abstract

11 Smoked cigarette filters a.k.a. "butts", composed of plastic (e.g. cellulose acetate) are one of 12 the world's most common litter items. In response to concerns about plastic pollution, biodegradable cellulose filters are being promoted as an environmentally safe alternative, however, once smoked, both contain toxins which can leach once discarded. The impacts of biodegradable butts as littered items on the receiving environment, in comparison with conventional butts has not yet been assessed. A freshwater mesocosm experiment was used to test the effects of leachate from smoked cellulose acetate versus smoked cellulose filters at a range of concentrations $\left(0,0.2,1\right.$ and 5 butts $\left.\mathrm{L}^{-1}\right)$ on the mortality and behaviour of four freshwater invertebrates (Dreissena polymorpha, Polycelis nigra, Planorbis planorbis and Bithynia tentaculata). Leachate derived from 5 butts $\mathrm{L}^{-1}$ of either type of filter caused $60-100 \%$ mortality to all species within 5 days. Leachate derived from 1 butt $\mathrm{L}^{-1}$ of either type resulted in adults being less active than those exposed to no or 0.2 butts $\mathrm{L}^{-1}$ leachate. Cigarette butts, therefore, regardless of their perceived degradability can cause mortality and decreased activity of key freshwater invertebrates and should always be disposed of responsibly. 
Key words: smoking, cigarette butts, leachate, molluscs, platyhelminth.

Capsule: As litter in enclosed aquatic habitats, conventional and biodegradable cigarette butts have the same effects causing mortality and behavioural changes to invertebrates.

\section{Introduction}

Cigarette butts (used cigarette filters) are the most common form of personal litter worldwide due to the majority ( $>75 \%$ ) of smokers littering them after use (Patel et al. 2013). Each year, $\sim 6$ trillion cigarettes are smoked globally, possibly resulting in an estimated deposition of $\sim 4.5$ trillion used cigarette butts in the environment (Novotny and Slaughter 2014). Despite their prevalence as litter in the environment, the effects of cigarette butts on marine, freshwater and terrestrial habitats is still vastly understudied. The majority $(\sim 90 \%)$ of cigarette filters are composed of cellulose acetate (Pauly et al. 2002), a type of plastic which is not readily biodegradable, but can break down into smaller pieces and persist as microplastics and nanoplastics (Chevalier et al. 2018). Cellulose acetate itself can cause environmental impacts as litter, with some studies finding that even unsmoked plastic filters can cause a detrimental effect on the receiving ecosystem, for example, decreasing plant growth (Green et al. 2019) causing mortality to fish (Slaughter et al. 2011) and amphibians (Lawal and Ologundudu 2013). In response to concerns about plastic, alternative materials, including pure, unbleached cellulose, are being promoted for use in cigarette filters instead of cellulose acetate plastic. These alternative filters have been described as "green", "biodegradable" and "environmentally friendly" giving the impression that these items would be benign as litter (Amos et al. 2017). There is, however, no research providing evidence of their level of toxicity as litter items nor any research comparing their effects with that of the cellulose acetate butts. 
48 As litter, cigarette butts present a unique combination of physical and chemical contamination.

Once smoked, cigarette butts contain thousands of chemicals including nicotine, polycyclic aromatic hydrocarbons and heavy metals which, once entering an aquatic environment, can leach out into the surrounding water (Moerman and Potts 2011; Roder Green et al. 2014; Dobaradaran et al. 2019). Such leachates are likely to pose a greater threat to lotic habitats that can have slow rates of water turnover such as ponds, low energy streams or rockpools than to habitats where the rate of water replacement is rapid (e.g. the ocean and in fast flowing streams and rivers). Indeed, leachate from smoked cigarette butts can be lethal for freshwater organisms such as microalgae, including Raphidocelis subcapitata (Bonanomi et al. 2020), water fleas, including Ceriodaphnia dúbia (Warne et al. 2002, Micevska et al. 2006), Daphnia magna (Register 2000), fish including Pimephales promelas (Slaughter et al. 2011) and amphibians including Hymenochirus curtipes and Clarias gariepinus (Lawal and Ologundudu 2013). Although mortality often occurs at high concentrations of cigarette butt leachate (> 1 butt $\left.\mathrm{L}^{-1}\right)$, sublethal impacts at lower, more environmentally realistic concentrations $\left(<0.2\right.$ butts $\left.\mathrm{L}^{-1}\right)$ have been observed, including mutagenic effects (Montalvão et al. 2019), developmental retardation (Lee and Lee 2015, Parker and Rayburn 2017) and alterations to behaviour (Booth et al. 2015; Wright et al. 2015). Such sublethal effects are often overlooked by policymakers, but may invoke important cascading ecological effects (Relyea and Hoverman 2006).

To explore toxicological effects of leachate from smoked cigarette butts at incremental concentrations, four different aquatic invertebrate species were studied in a controlled environment. The selected organisms included Dreissena polymorpha (Pallas 1771) (zebra mussel), Polycelis nigra (Müller 1774) (a flatworm), Planorbis planorbis (Linnaeus 1758) (ramshorn snail) and Bithynia tentaculata (Linnaeus 1758) (faucet snail). These were chosen as model organisms as each are commonly found in pond ecosystems across Europe and the UK and fulfil a range of ecosystem functions (as e.g. detritivores, grazers, filter feeders, 
predators and prey organisms). Here, lethal (mortality) and sublethal (behaviour) effects were measured in response to leachate derived from smoked cigarettes with either conventional cellulose acetate filters or biodegradable cellulose filters. The hypothesis tested was that alternative, cellulose cigarette butts would not cause the same lethal and sublethal effects as conventional, cellulose acetate cigarette butts on the aquatic invertebrates.

\section{Materials and methods}

\subsection{Preparation of leachate from smoked cigarette filters}

Cigarettes were rolled manually using standard cigarette papers to an average ( \pm S.E.) of 0.543 $\pm 0.002 \mathrm{~g}$ per cigarette of a leading brand of tobacco in the UK, with either a cellulose acetate or a cellulose (unbleached) filter. All cigarettes were smoked using a hand-operated vacuum pump with silicone tubing attached to the filter of the cigarettes. After lighting, approximately $30( \pm 1) \mathrm{ml}$ of air was drawn in, simulating a draft and each cigarette was smoked for a total inhalation volume of $\sim 600 \mathrm{ml}$ per cigarette, thereby emulating a similar total inhalation volume of cigarettes smoked by humans $(585 \pm 245) \mathrm{ml}$; McBride et al. 1984). Cigarettes were smoked until $2 \mathrm{~mm}$ from the edge of the filter and stubbed out in an aluminium tray. Any remaining tobacco was removed, leaving the filter with the cigarette paper attached. A stock solution of leachate from each type of filter used (cellulose and cellulose acetate) was prepared separately by soaking 14 smoked butts in $1 \mathrm{~L}$ of fresh, filtered $(20 \mu \mathrm{m})$ rainwater obtained from an artificial pond in glass volumetric flasks and gently agitating (100 rpm) on an orbital shaker for $18 \mathrm{~h}$ at room temperature $\left(\sim 18^{\circ} \mathrm{C}\right)$. Rainwater was chosen to represent how cigarettes butts may experience leaching when exposed to precipitation in the environment. Furthermore, rainwater resembles pond water more closely than media such as distilled water. Rainwater has been shown to also leach potential contaminants from cigarette butts (e.g. Koutela et al. 2020). 


\subsection{Mesocosm set-up and experimental design}

The experiment was carried out in a temperature and light controlled facility at the Portaferry Marine Laboratory with a 12/12 h light/dark cycle. Mesocosms were set up in the laboratory, using conical glasses ( $86 \mathrm{~mm}$ diameter at top, $65 \mathrm{~mm}$ diameter at bottom) that were filled with rainwater $(400 \mathrm{ml})$, extracted from the same artificial pond as the test organisms, and left to settle without any added leachate for $24 \mathrm{~h}$ before the experimental exposures were initiated. On day $1\left(19^{\text {th }}\right.$ March, 2020) of the experiment, treatments were randomly assigned to mesocosms and corresponding leachate was added by removing the required volume of water and substituting with $5.7,28.6$ or $142.8 \mathrm{ml}$ of stock leachate representing incremental concentrations based on $0.2,1$ or 5 smoked butts $\mathrm{L}^{-1}$ of either cellulose or cellulose acetate smoked filters. The experimental organisms including D. polymorpha, P. nigra, P. planorbis and $B$. tentaculata were harvested using a net from an artificial pond $(1.4 \times 2.1 \times 0.9 \mathrm{~m})$. One individual of each species was added to each mesocosm along with five $B$. tentaculata juveniles thereby creating representative communities of similar densities to those found in the sampled pond (Table S1). A treatment with no added leachate served as a control. Therefore, the experiment consisted of an asymmetric design with 2 fixed factors; "Butts" ( 2 levels; cellulose versus cellulose acetate filters) and "Concentration" ( 3 levels; $0.2,1$ and 5 butts $\mathrm{L}^{-1}$ added as leachate). Each treatment was replicated using 5 separate mesocosms $(n=5, N=35)$ (Figure 1). Water temperature within the mesocosms had an average $\mathrm{pH}$ of $8.13( \pm 0.02)$, salinity < $0.05 \mathrm{ppt}$ and was maintained at $15( \pm 0.42){ }^{\circ} \mathrm{C}$ throughout the experiment.

The experiment was repeatedly sampled every $24 \mathrm{~h}$ for a total of $120 \mathrm{~h}$. At each sampling occasion, mortality was recorded and a number of behavioural observations were recorded into categories including (i) filtering or (ii) closed for the bivalves, (i) moving, (ii) open (antennae and foot extended) or (iii) closed (antennae and foot withdrawn into shell) for the gastropods and (i) moving, (ii) open (body elongated) or (iii) closed (body compressed into a spherical 
shape) for the flatworms. Observations were made in real time by the same observer each time. Due to the high mortality rate in the 5 butts $\mathrm{L}^{-1}$ treatments, behavioural observations were only recorded for mesocosms exposed to $0,0.2$ or 1 butt $\mathrm{L}^{-1}$.

\subsection{Statistical analysis}

Mortality data was categorised into a mortality scale ranging from 0 to 5 with " 0 " meaning no mortality at the end of the experiment and "1", "2", "3", "4" and "5" meaning that death occurred after $>120,96,72,48$ and 24 hours respectively. In this way, the higher the number, the more rapidly the animal died representing a more lethal effect. The survival of juvenile $B$. tentaculata was converted to percentage out of 5 which were still alive at each time point. Mortality and juvenile survival were analysed using asymmetrical ANOVA (see e.g. Green et al. 2016 for more details) to account for a single set of control units for the two experimental levels Butt and Concentration. The survival of juvenile B. tentaculata was analysed separately for each time point to avoid complications involved with repeated measures. Univariate data were screened for normality and homogeneity of variance to check assumptions of ANOVA and any necessary transformations are where appropriate. Statistical analyses were done using R V.3.6.2 (R Core Team 2019).

To test effects of leachate on the behaviour over the duration of the experiment, the behavioural data over the course of the 5 days was pooled and analysed mirroring the univariate analysis except with only 2 levels of leachate concentration $\left(0.1\right.$ and 1 butt $\left.\mathrm{L}^{-1}\right)$ instead of three due to the removal of the 5 butts $\mathrm{L}^{-1}$ treatment. Multivariate ANOVA was done on Bray-Curtis dissimilarities of untransformed data with 9999 permutations under the reduced model using Type I SS using the vegan package v2.5-2 (Oksanen et al. 2019). The asymmetric analysis was done by fitting each main effect ('Butt' and 'Concentration') in turn with a Type I (sequential) SS model, swapping the order of the terms and combining the results of these 2 analyses. The 
multivariate behaviour data were visualised using a non-metric multidimensional scaling ordination approach reflecting the dissimilarity matrix used for the PERMANOVA with variables with a Pearson's correlation $\mathrm{R}>0.6$ overlain as vectors. SIMPER was used to elucidate which behaviours were driving the significant differences between treatments (contributing $>5 \%$ to the dissimilarity) found by PERMANOVA analysis. Note that behavioural data is a sublethal response variable so data from either of the 5 butts $\mathrm{L}^{-1}$ treatments was omitted since there was a high instance of mortality in these treatments. The nMDS and the SIMPER analyses were generated using Primer V6.1.13 (PRIMER-e, Plymouth, UK).

\section{Results}

\subsection{Effects of leachate from smoked cigarette butts on mortality of aquatic invertebrates.}

At 5 butts $\mathrm{L}^{-1}$ most of D. polymorpha, P. planorbis, B. tentaculta and P. nigra died after 72 hours of exposure on average (Figure 1), which was significantly (Table 1) different from mesocosms treated with 1 butt $\mathrm{L}^{-1}$ (Concentration [5 vs 1 butt $\mathrm{L}^{-1}$ ]: $\mathrm{P}<0.001$ ), 0.2 butt $\mathrm{L}^{-1}$ (Concentration [5 vs 0.2 butt $\mathrm{L}^{-1}$ ]: $\mathrm{P}<0.001$ ) or mesocosm with no leachate (Concentration [5 butt $\mathrm{L}^{-1}$ vs control]: $\left.\mathrm{P}<0.001\right)$. There was no significant difference between survival of the test organisms based on leachate derived from cellulose versus cellulose acetate butts (Table 1).

Significantly fewer juvenile $B$. tentaculata survived in mesocosms with either 5 butts $\mathrm{L}^{-1}$ of cellulose acetate or cellulose butts compared with controls with less than $20 \%$ surviving even after just $24 \mathrm{~h}$ (Table 1, Concentration [Control vs 5 cellulose butts $\mathrm{L}^{-1}$ ]: $\mathrm{P}<0.001$, Concentration [control vs 5 cellulose acetate butts $\mathrm{L}^{-1}$ ]: $\mathrm{P}<0.001$ for each time point). After 48 and 72 h, survival with 1 cellulose acetate butt $\mathrm{L}^{-1}$ was $\sim 50 \%$ which was significantly lower than in the Controls (Control vs 1 cellulose acetate butt $\mathrm{L}^{-1}: \mathrm{P}<0.001$ at 48 and $72 \mathrm{~h}$ ). At the same time points (48 and $72 \mathrm{~h}$ ) 1 cellulose butt L-1 did not have a significant effect on survival (Control vs 1 cellulose butt $\mathrm{L}^{-1}: \mathrm{P}=0.690$ ). After $120 \mathrm{~h}$, however, there were no differences 
between cellulose acetate and cellulose butts and 1 butt $\mathrm{L}^{-1}$ of either type caused survival to drop to $\sim 30 \%$ (Table 1, Figure 2). In addition, by $120 \mathrm{~h}$, survival decreased with increasing concentration of leachate with $100 \%$ survival at 0.2 butts $\mathrm{L}^{-1}, \sim 30 \%$ at 1 butt $\mathrm{L}^{-1}$ and $<5 \%$ at 5 butts $\mathrm{L}^{-1}$ (post-hoc tests for concentration at $120 \mathrm{~h} ; 0.2$ vs 1 : $\mathrm{P}<0.001,0.2$ vs 5 : $\mathrm{P}<0.001$ and 1 vs $5: \mathrm{P}<0.001)$.

\subsection{Sub-lethal effects of leachate from smoked cigarette butts on aquatic invertebrates.}

Behaviour of the surviving individuals did not significantly differ (Figure 3 ) regardless of the source of the leachate (Butt [cellulose vs cellulose acetate], $\mathrm{P}=0.458$ ). The concentration of leachate, however, did significantly alter patterns of behaviour. In particular, the mesocosms exposed to 1 butt $\mathrm{L}^{-1}$ exhibited different types of behaviour compared to those in mesocosms with 0.2 butts $\mathrm{L}^{-1}$ or no leachate (Concentration [control vs 1 butt $\left.\mathrm{L}^{-1}\right]$ : $\mathrm{P}<0.003$ and $[0.2$ vs 1 butt $\left.\mathrm{L}^{-1}\right]: \mathrm{P}=0.002$ ). These differences were mostly due to a greater occurrence of movement or filtering in the case of D. polymorpha (accounting for $\sim 40 \%$ of the variation in the multivariate pattern), and less occurrence of being in a closed state (accounting for $\sim 38 \%$ of the variation in the multivariate pattern), of all four species in mesocosms without leachate or with 0.2 butts $\mathrm{L}^{-1}$ leachate compared with those in leachate from 1 butt $\mathrm{L}^{-1}$ (Figure 3 ).

\section{Discussion}

Cigarette butt leachate derived from biodegradable (i.e. cellulose) filters was equally as detrimental to freshwater pond invertebrates as leachate derived from conventional (i.e. cellulose acetate) filters. Leachate from 5 butts $\mathrm{L}^{-1}$ derived from either type of butt was lethal to $\sim 60 \%$ of adult $P$. nigra, P. planorbis and B. tentaculata and to $\sim 40 \%$ of adult D. polymorpha within 48 hours. This is similar, albeit less lethal, to the results of Booth et al. (2015) who found $100 \%$ mortality of two species of marine gastropod (Austrocochlea porcata and Nerita 
atramentosa) after 24 hours of continuous exposure to leachate from 5 butts $\mathrm{L}^{-1}$, but $100 \%$ mortality of a third species (Bembecium nanum) did not occur until 150 hours.

In the current study, mortality of adults was low at exposure to leachate from 1 butt $\mathrm{L}^{-1}$ equivalent and no animals died during the experimental period in mesocosms with no or just 0.2 butts $\mathrm{L}^{-1}$ equivalent of leachate. Juvenile $B$. tentaculata, however, were more sensitive to 1 butt $\mathrm{L}^{-1}$ than their adult counterparts with only $\sim 30 \%$ of juveniles surviving after $120 \mathrm{~h}$ of exposure versus $\sim 80 \%$ of adults. This is not surprising given that early life stages of invertebrates are typically more sensitive to toxicants and hence are often prioritised for use in ecotoxicological studies (Mohammed 2013). For example, early life stage (ELS) tests (such as OECD 2018) are widely conducted to estimate toxicity for the registration of industrial chemicals, pesticides, biocides, and pharmaceuticals. Early life stages are also important ecologically because a reduction in successful recruitment can result in changes to population dynamics over the longer term and cause shifts in freshwater biodiversity and ecosystem functioning (Strayer and Malcom 2012).

It is important to measure sublethal responses to contaminants as these may be ecologically important, for example, movement facilitates feeding, predator avoidance, reproduction and migration and so can link effects on individuals to a population level (Bayley et al. 1997). Even though there was little mortality of adults at 1 butt $\mathrm{L}^{-1}$ of leachate, significant alterations to behaviour did occur whereby the test animals were less active. It is likely that this indicates that they were under stress and in the longer-term this may have led to mortality (Rubach et al. 2011). In a study by Wright et al (2015), a marine polychaete (Hediste diversicolor) was also found to be less active, decreasing burrowing in response to $>2$ butts $\mathrm{L}^{-1}$ leachate. Alteration to behaviour also occurred in marine gastropods exposed to 1.25 butts $\mathrm{L}^{-1}$, but this differed depending on the species (Booth et al. 2015). Lee and Lee (2015) found contrasting effects at increasing concentrations of cigarette butt leachate, with significantly increased heart rates and 
accelerated embryonic development at lower concentrations $\left(0.2-2\right.$ butts $\left.\mathrm{L}^{-1}\right)$, but lower heart rates and suppressed development at high concentrations (5 - 10 butts $\left.\mathrm{L}^{-1}\right)$. In addition, Montalvão et al. (2019) found that freshwater mussels, Anadontites trapesialis, exposed to leachate from smoked cigarette butts accumulated heavy metals in their tissues and experienced mutagenetic effects even at low environmentally relevant concentrations $\left(<0.2\right.$ butts $\left.\mathrm{L}^{-1}\right)$, although the treatments were pseudo-replicated. Therefore, the response over time to sublethal toxicity may manifest in factors such as reproduction or growth performance, important for population sustainability and warrants further investigation.

We currently know very little about how the toxicity of cigarette butts may change over time when in the environment, but recent research indicates that butts continue to exude toxic chemicals into the air at least 1 week after being extinguished (Gong et al. 2020). Furthermore, Bonanomi et al. (2020) found that cellulose acetate cigarette butts remained toxic to the microalga Raphidocelis subcapitata after 5 years of degradation in the terrestrial environment. Whether or not cellulose cigarette butts also remain toxic for this length of time is unknown but should be a priority of future work in order to ascertain comparative effects of these different filter materials. International testing standards designed to evaluate the biodegradability of materials for use in cigarette butts do not test biodegradation after smoking, therefore are not environmentally realistic and when smoked, cellulose cigarette butts deposited as litter in the environment can also persist for years (Joly and Coulis 2018).

\section{Conclusion}

Overall, leachate from either type of butt at 5 butts $\mathrm{L}^{-1}$ caused mortality of most of the individuals in the experiment. Additionally, at 1 butt $\mathrm{L}^{-1}$, both types of butt had a lethal effect on juvenile snails and reduced the activity levels of all four species of invertebrate. This 
emphasises that, once smoked, cigarette filters, biodegradable or not, therefore are likely to

247 have a detrimental effect on the environment due to toxins concentrated from smoking tobacco.

248 Filters manufactured of cellulose, once smoked, can pose the same ecological threat as 249 conventional cellulose acetate butts if they become litter in an enclosed water body such as a 250 lake or pond. Considering their lack of rapid biodegradation in terrestrial habitats and their toxic effects in freshwater habitats, any shift to cellulose cigarette filters should be

252

253

254

255

256

257

258

259

260

261

262

263

264

265

266

267

268

\section{Acknowledgements}

We would like to thank Anglia Ruskin University for granting Dr Green a research sabbatical and Emma Gorman for maintaining laboratory facilities at Portaferry.

\section{References}

Amos, C., Allred, A. \& Zhang, L. 2017. Do Biodegradable Labels Lead to an Eco-safety Halo Effect? J Consum Policy 40, 279-298.

Bayley M, Baatrup E, Bjerregaard P. 1997. Woodlouse locomotor behavior in the assessment of clean and contaminated field sites. Environ Toxicol Chem. 16:2309-2314.

Bonanomi G, Maisto G, De Marco A, Cesarano G, Zotti M, Mazzei P, Libralato G, Staropoli A, Siciliano A, De Filippis F, La Storia A, Piccolo A, Vinale F, Crasto A, Guida M, Ercolini D, Incerti G. 2020. The fate of cigarette butts in different environments: Decay rate, chemical changes and ecotoxicity revealed by a 5-years decomposition experiment. Environmental Pollution, Volume 261,114108. 
Booth DJ, Gribben P, Parkinson K. 2015. Impact of cigarette butt leachate on tidepool snails.

271 Chevalier Q, Hadri HE, Petitjean P, Le Coz MB, Reynaud S, Grassl B, Gigault J. 2018.

272 Nano-litter from cigarette butts: Environmental implications and urgent consideration,

273 Chemosphere, 194: 125-130.

Dobaradaran S, Schmidt TC, Lorenzo-Parodi N, Jochmann MA, Nabipour I, Raeisi A,

Stojanović N, Mahmoodi M. 2019. Cigarette butts: An overlooked source of PAHs in the environment? Environmental Pollution, 249: 932-939.

Gong M, Daniels N, Poppendieck D. 2020. Measurement of chemical emission rates from cigarette butts into air. Indoor Air, 00: 1- 14 .

Green DS, Boots B, Carvalho J, Starkey T. 2019. Cigarette butts have adverse effects on initial growth of perennial ryegrass (gramineae: Lolium perenne L.) and white clover (leguminosae: Trifolium repens L.). Ecotoxicology and Environmental Safety, 182: 109418. biodegradable microplastics on a marine ecosystem engineer (Arenicola marina) and sediment nutrient cycling. Environmental Pollution, 208: 426-434.

Koutela N, Fernández E, Saru ML, Psillakis E. 2020. A comprehensive study on the leaching of metals from heated tobacco sticks and cigarettes in water and natural waters. Science of The Total Environment. 714. 136700. curtipes and Clarias gariepinus in Nigeria. J Environ Ext 11:7-14.

Lee W, Lee CC. 2015. Developmental toxicity of cigarette butts - An underdeveloped issue. Ecotoxicology and Environmental Safety, 113: 362-368. 
Joly FX, Coulis M, 2018. Comparison of cellulose vs. plastic cigarette filter decomposition under distinct disposal environments. Waste Management, 72: 349-353.

McBride MJ, Guyatt AR, Kirkham AJ, Cumming G. 1984. Assessment of smoking behaviour and ventilation with cigarettes of differing nicotine yields. Clin Sci (Lond) 67:619-31.

Micevska T, Warne MS, Pablo T, Patra R. 2006. Variation in, and causes of, toxicity of CB to a cladoceran and microtox. Arch. Environ. Contam. Toxicol., 50, pp. 205-212.

Moerman JW, Potts GE. 2011. Analysis of metals leached from smoked cigarette litter. Tobacco Control, 20: 30-35.

Mohammed A. 2013. Why are Early Life Stages of Aquatic Organisms more Sensitive to Toxicants than Adults? New Insights into Toxicity and Drug Testing. Gowder S (Ed). DOI: 10.5772/55187 Available from: https://www.intechopen.com/books.

Montalvão MF, Chagas TQ, da Silva Alvarez TG, Mesak C, da Costa Araújo AP, Gomes AR, Vieira JE, Malafaia G. 2019. How leachates from wasted cigarette butts influence aquatic life? A case study on freshwater mussel Anodontites trapesiali. Science of The Total Environment, 689: 381-389.

Novotny TE, Slaughter E. 2014. Tobacco product waste: an environmental approach to reduce tobacco consumption. Curr. Environ. Health Rpt, 1: 208-216.

OECD (2018), "Fish, Early-Life Stage (FELS) Toxicity Test (OECD TG 210)", in Revised Guidance Document 150 on Standardised Test Guidelines for Evaluating Chemicals for Endocrine Disruption, OECD Publishing, Paris, https://doi.org/10.1787/9789264304741-13en.

Oksanen J, Guillaume Blanchet F, Friendly M, Kindt R, Legendre P, McGlinn 

Vegan: community Ecology Package. R Package Version 2.5-2. Available: https://cran.rproject.org/web/packages/vegan/vegan.pdf.

317 Patel V, Thomson GW, Wilson N. 2013. Cigarette butt littering in city streets: a new methodology for studying and results. Tob. Control, 22: 59-62

Parker TT, Rayburn J. 2017. A comparison of electronic and traditional cigarette butt leachate on the development of Xenopus laevis embryos. Toxicology Reports 4: 77-82.

Pauly JL, Mepani AB, Lesses JD, Cummings KM, Streck RJ. 2002. Cigarettes with defective filters marketed for 40 years: what Philip Morris never told smokers. Tob Control. 2002 Mar;11 Suppl 1: I51-61.

R Core Team. 2019. R: A language and environment for statistical computing. R Foundation for Statistical Computing, Vienna, Austria. URL https://www.R-project.org/ Littoral Society, 25: 23-29.

Relyea R, Hoverman J. 2006. Assessing the ecology in ecotoxicology: a review andsynthesis in freshwater systems. Ecology Letters, 9: 1157-1171.

Roder Green AL, Putschew A, Nehls T. 2014. Littered cigarette butts as a source of nicotine in urban waters. Journal of Hydrology, 519: 3466-3474.

Rubach MN, Crum SJH, Van den Brink PJ. 2011. Variability in the dynamics of mortality and immobility responses of freshwater arthropods exposed to chlorpyrifos. Arch Environ Contam Toxicol. 60:708-721. 
335 Slaughter E, Gersberg EM, Watanabe K, Rudolph J, Stransky C, Novotny TE. 2011. Toxicity 336 of CB, and their chemical components, to marine and freshwater fish. Tob. Control, 20: 2533729.

338 Strayer DL, Malcom HM. 2012. Causes of recruitment failure in freshwater mussel 339 populations in southeastern New York. Ecological Applications, 22: 1780-1790.

340 Wright SL, Rowe D, Reid MJ, Thomas KV, Galloway TS. 2015. Bioaccumulation and 341 biological effects of cigarette litter in marine worms. Scientific Reports, 5:14119. 
343 Table 1. Results of asymmetrical ANOVA for (a) the lethality of leachate to each species

344 throughout the experiment and (b) the survival of juvenile $B$. tentaculata at each time point

345 (from 24 to 120 h). d.f. $=$ degrees of freedom, $F=$ F-ratio and $p=$ p-value. Significance at $\alpha<$ $346 \quad 0.05$ and is indicated by values in bold.

\begin{tabular}{|c|c|c|c|c|c|c|c|c|c|}
\hline \multirow{2}{*}{$\begin{array}{l}\text { (a) } \\
\text { Source of variation }\end{array}$} & \multirow[b]{2}{*}{ d.f. } & \multicolumn{2}{|c|}{ D. polymorpha } & \multicolumn{2}{|c|}{$P$. nigra } & \multicolumn{2}{|c|}{ P. planorbis } & \multicolumn{2}{|c|}{ B. tentaculata } \\
\hline & & $F$ & $p$ & $F$ & $p$ & $F$ & $p$ & $F$ & $p$ \\
\hline Treatment (one way) & 6 & 8.63 & $<0.001$ & 15.72 & $<0.001$ & 4.47 & 0.003 & 10.64 & $<0.001$ \\
\hline Control vs others & 1 & 1.93 & 0.175 & 3.72 & 0.064 & 2.27 & 0.143 & 5.31 & 0.029 \\
\hline Butt (B) & 1 & 1.27 & 0.297 & 2.62 & 0.090 & 0.07 & 0.930 & 0.72 & 0.497 \\
\hline Concentration (C) & 2 & 22.37 & $<0.001$ & 40.85 & $<0.001$ & 11.97 & $<0.001$ & 27.82 & $<0.001$ \\
\hline $\mathrm{B} \times \mathrm{C}$ & 2 & 1.27 & 0.297 & 1.85 & 0.176 & 0.24 & 0.791 & 0.72 & 0.497 \\
\hline Residuals & 52 & & & & & & & & \\
\hline
\end{tabular}

\begin{tabular}{lrrrrrrrrrrr}
\hline (b) & & \multicolumn{2}{c}{$24 \mathrm{~h}$} & \multicolumn{2}{c}{$48 \mathrm{~h}$} & \multicolumn{2}{c}{$72 \mathrm{~h}$} & \multicolumn{2}{c}{$96 \mathrm{~h}$} & \multicolumn{1}{c}{$120 \mathrm{~h}$} \\
\cline { 2 - 12 } Source of variation & d.f. & \multicolumn{1}{c}{$F$} & \multicolumn{1}{c}{$p$} & \multicolumn{1}{c}{$F$} & \multicolumn{1}{c}{$p$} & \multicolumn{1}{c}{$F$} & $p$ & \multicolumn{1}{c}{$p$} & \multicolumn{1}{c}{$F$} & \multicolumn{1}{c}{$p$} \\
\hline Treatment (one way) & 6 & $\mathbf{1 0 . 6 4}$ & $<\mathbf{0 . 0 0 1}$ & $\mathbf{3 9 . 3 1}$ & $<\mathbf{0 . 0 0 1}$ & $\mathbf{5 4 . 6 7}$ & $<\mathbf{0 . 0 0 1}$ & $\mathbf{5 0 . 3 7}$ & $<\mathbf{0 . 0 0 1}$ & $\mathbf{3 5 . 4 7}$ & $<\mathbf{0 . 0 0 1}$ \\
Control vs others & 1 & $\mathbf{5 . 3 1}$ & $\mathbf{0 . 0 2 9}$ & $\mathbf{2 7 . 5 3}$ & $<\mathbf{0 . 0 0 1}$ & $\mathbf{4 4 . 1 6}$ & $<\mathbf{0 . 0 0 1}$ & $\mathbf{4 8 . 2 6}$ & $<\mathbf{0 . 0 0 1}$ & $\mathbf{5 4 . 4 0}$ & $<\mathbf{0 . 0 0 1}$ \\
Butt (B) & 1 & 0.72 & 0.497 & 2.60 & 0.092 & 2.71 & 0.084 & 1.13 & 0.338 & 0.70 & 0.504 \\
Concentration (C) & 2 & $\mathbf{2 7 . 8 2}$ & $<\mathbf{0 . 0 0 1}$ & $\mathbf{9 6 . 1 0}$ & $<\mathbf{0 . 0 0 1}$ & $\mathbf{1 3 2 . 8 8}$ & $<\mathbf{0 . 0 0 1}$ & $\mathbf{1 2 2 . 1 9}$ & $<\mathbf{0 . 0 0 1}$ & $\mathbf{7 6 . 2 1}$ & $<\mathbf{0 . 0 0 1}$ \\
B x C & 2 & 0.72 & 0.497 & 5.47 & 0.010 & 6.33 & 0.005 & 3.67 & 0.039 & 2.29 & 0.120 \\
Residuals & 52 & & & & & & & & & & \\
\hline
\end{tabular}




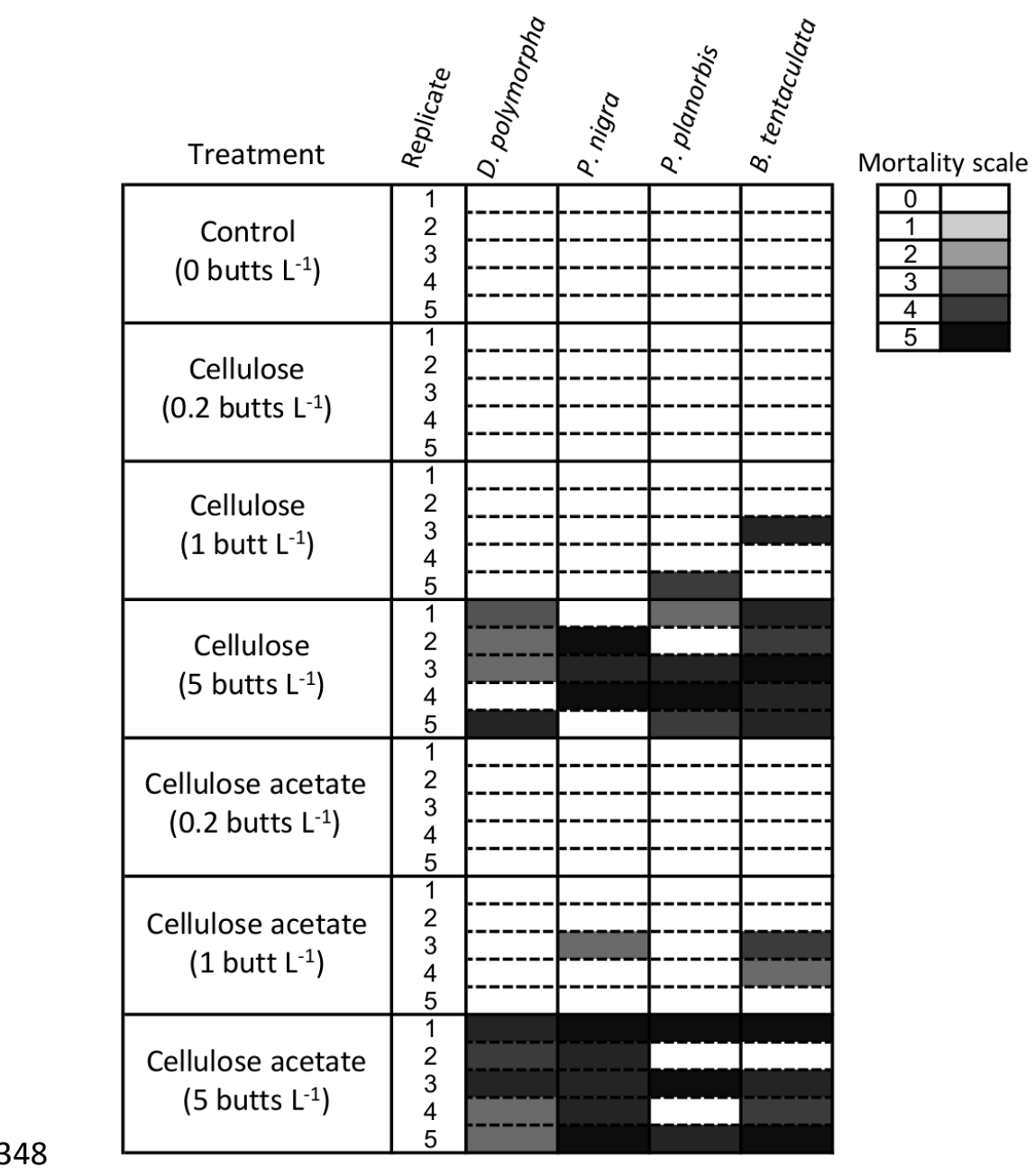

349 Figure 1. Heatmap showing the lethality of leachate derived from smoked cigarettes butts 350 made from either cellulose or cellulose acetate filters on D. polymorpha, P. nigra, P. planorbis 351 and B. tentaculata for each replicate mesocosm. Mortality scale is shown and is based on the 352 time taken for death to occur, i.e. the darker the cell, the higher the mortality in a replicate 353 mesocom, with 0 the least lethal (no deaths within $120 \mathrm{~h}$ ) and 5 the most lethal (died within 24 $354 \mathrm{~h})$. 


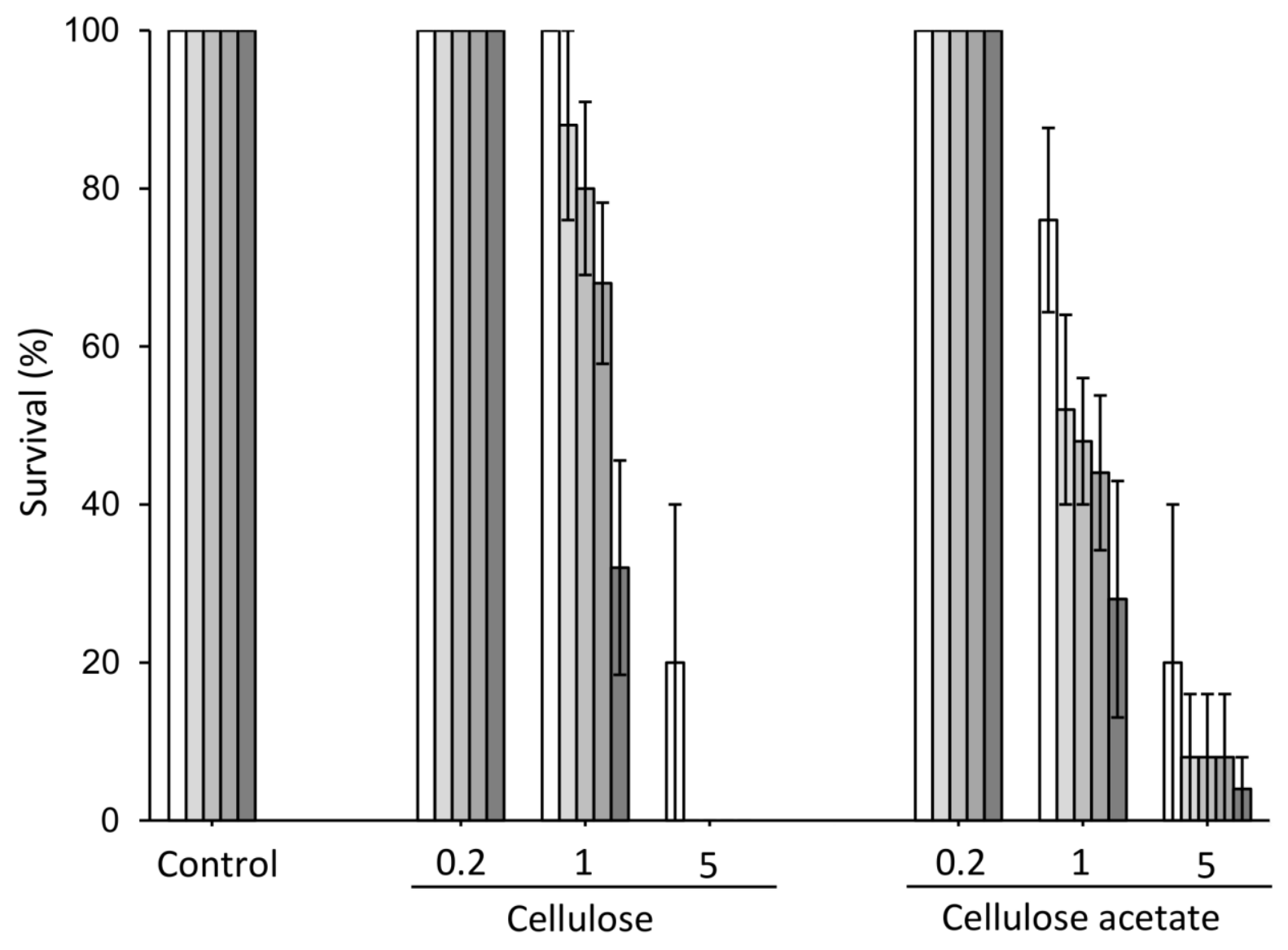

357 Figure 2. Survival (\%) out of 5 individual juvenile $B$. tentaculata snails in either rainwater

358 without leachate (Control) and leachate from $0.2,1$ or 5 cellulose, or cellulose acetate butts $\mathrm{L}^{-}$

$359{ }^{1}$ at $24(\square), 48(\square), 72(\square), 96(\square)$ and >120 ( $\square$ ) hours of exposure. Data are mean \pm SEM, n $360=5$. 


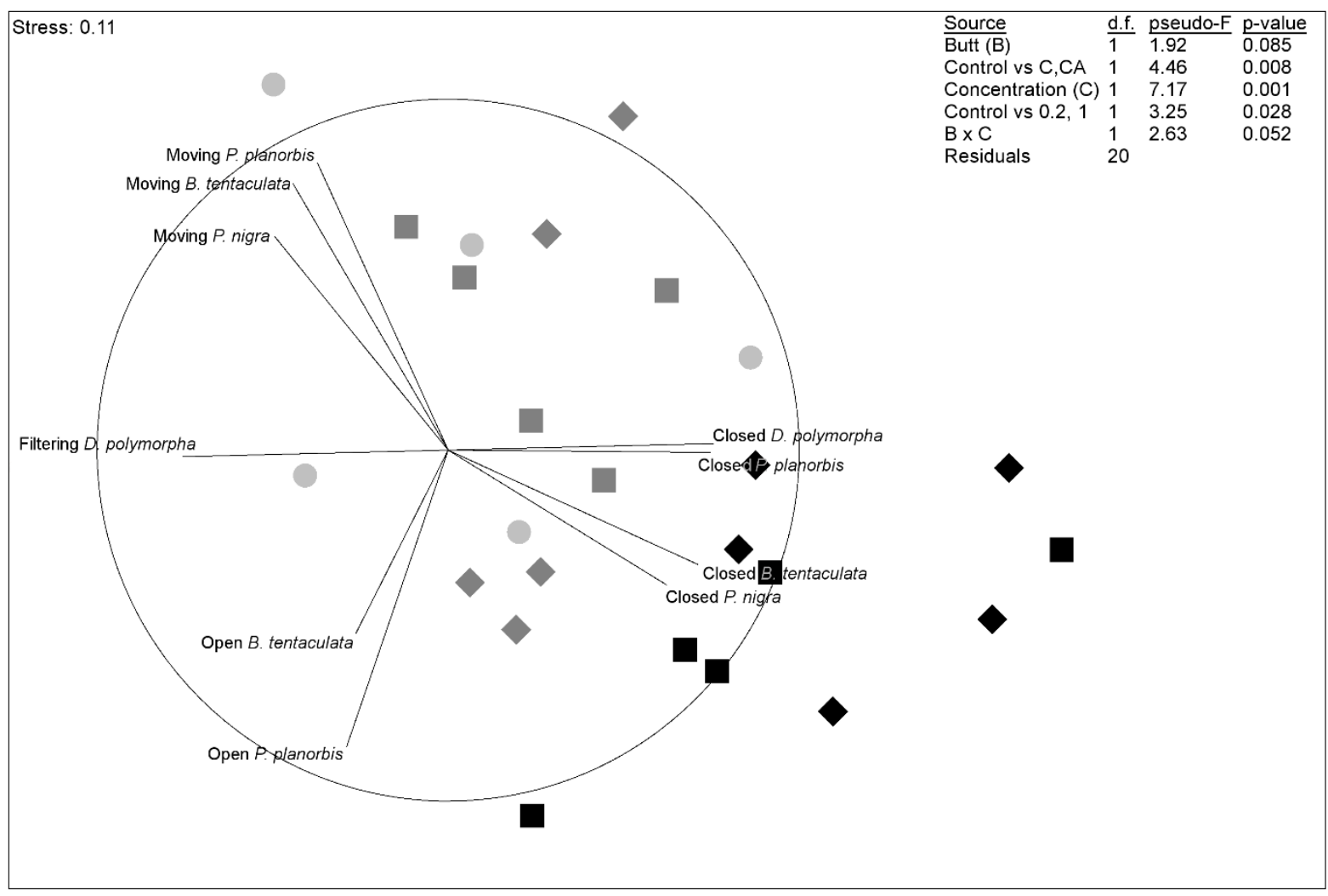

Figure 3. Non-metric multidimensional scaling diagram of the behaviour exhibited by all

363 species pooled over the 5 days of the experiment exposed to either no leachate $(O)$ or to leachate

364 from $0.2(\diamond)$ or $1(\diamond)$ cellulose butts $\mathrm{L}^{-1}$ or to $0.2(\square)$ or $1(\square)$ cellulose acetate butts $\mathrm{L}^{-1}$.

365 Vectors are overlain for behaviours classifications correlated to the multivariate pattern at $r>$

366 0.6. Included are results of the asymmetric PERMANOVA analysis, with associated pseudo-F

367 values and observed p-values based on 9999 permutations of the data. 